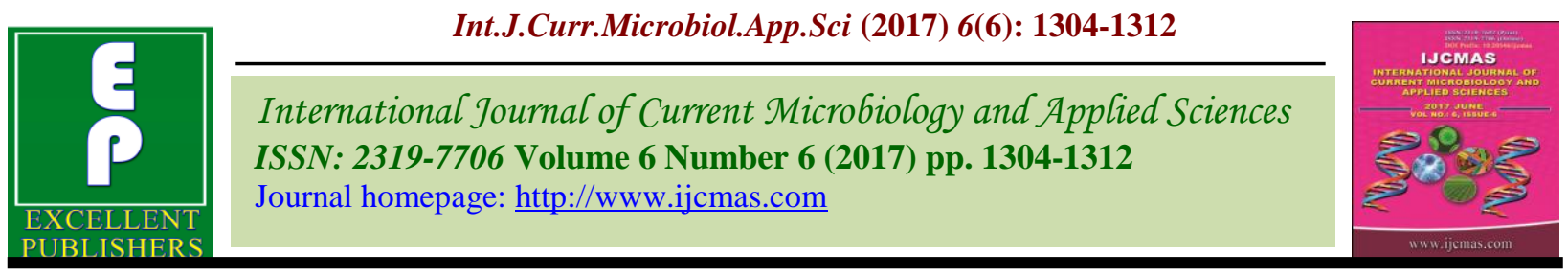

Original Research Article https://doi.org/10.20546/ijcmas.2017.606.153

\title{
Study on Impact of Farmer's Participatory Varietal Selection in Groundnut (Arachis hypogeae L.) Improvement
}

\author{
Hasan Khan*, Vinay S. Patted, B. Muralidhara, I. Shankergoud and P.M. Salimath \\ Department of Genetics and Plant Breeding, UAS, Raichur, Karnataka, India \\ *Corresponding author
}

A B S T R A C T

The experiment was conducted during kharif-2015 and rabi/summer 2015-16 in selected districts of Hyderabad-Karnataka region. Farmer's Participatory Varietal Selection

\begin{tabular}{|l|}
\hline Key w or d s \\
Groundnut, \\
Participatory, \\
Selection, Mother- \\
baby trail, Varieties. \\
\hline Article Info \\
\hline Accepted: \\
19 May 2017 \\
Available Online: \\
10 June 2017 \\
\hline \hline
\end{tabular}
approach was used to evaluate 10 groundnut varieties in farmer fields by the farmers. Based on pooled mean performance of test genotypes for dry pod yield ( $\mathrm{kg} / \mathrm{ha}$ ) across locations during kharif-2015, the test genotypes GPBD-5 (1572 kg/ha), Kadiri-9 (1492 $\mathrm{kg} / \mathrm{ha})$ and ICGV-00351 (1481 kg/ha) were found to be statistically significant over local check (1267 kg/ha) and in rabi/summer, the ICGV-00351 (1693 kg/ha), GPBD-5 (1649 $\mathrm{kg} / \mathrm{ha}$ ) and Kadiri-9 (1589 kg/ha) were performed statistically significant over local check (1406 kg/ha) across the locations. With respect to farmers preference during kharif, Kadiri$9(22.70 \%)$, GPBD-5 (15.52 \%) and Dharani (15\%) were most preferred varieties, where in rabi/summer, Kadiri-9 (22.70\%), Dharani (16.91\%) and GPBD-5 (12.84 \%) were most preferred varieties. The varietal preference among the groundnut stakeholders revealed that, Kadiri-9 being most preferred variety with total rankings of 19, which is followed by ICGV-00351, Kadiri-haritendra, TPG-41, TMV-2, G2-52 and GPBD-5 with total rankings of 18 based on the mean preference of the traits like Seed size, seed shape, test a colour, pod size, pod shape, pod filling, shelling (\%), oil content and market price.

\section{Introduction}

The groundnut is one of the important crop of tropical and semiarid tropical countries, ranks 6th in world edible oil production among the oilseed crops and 3rd most important source of vegetable protein. It is consumed directly as raw, roasted and boiled nuts or processed into confections and groundnut flour for flavour enhancement or crushed for edible oil and industrial uses including haulm and shell used as fodder (Pande et al., 2003; Upadhyaya et al., 2006). Despite of its diversified uses, groundnut cultivated area declining year by year since two decades as illustrated by significant decline in area from
$0.85 \mathrm{~m}$ ha in $2001-02$ to around $0.65 \mathrm{~m}$ ha in 2013-14 (Ministry of agriculture, Govt. of India). In Karnataka the productivity is very low at $863 \mathrm{~kg}$ ha- 1 compared to the national average about $1764 \mathrm{~kg} \mathrm{ha}^{-1}$ in 2013-14 (Ministry of agriculture, Govt. of India).

The lower productivity in groundnut is mainly due to various biotic and abiotic stresses. Apart from these, cultivation of age old varieties which are vulnerable to majority of pests and diseases and non-availability of improved quality seeds also plays role. Many a times, improved varieties will not reach to 
farmers due to inefficient extension system and they may not meet the expectations of farmers, trader's, agro-based industries and other stakeholders. In Karnataka TMV 2 occupies larger area due to premium price it fetches in the market because of its uniform pod and kernel features and wider adaptability but highly susceptible to pest and diseases. In order to address this problem, it has become essential to develop varieties that are high yielding with better pod and kernel features similar to TMV 2 and have wider adaptability.

Participatory plant breeding is the development of a plant breeding programme in collaboration between breeders and farmers, marketers, processors, consumers and policy makers (Walker, 2007 and Joshi and Witcombe, 1995). It's found to be effective and efficient tool in disseminating the improved varieties to farmers and to address present and future issues in farming. It acts as a bridge between scientific community and farmers wisdom, hence this mutual effect bring sustainability in crop improvement, which ultimately results in economic benefit and secured livelihood (Ceccarelli and Grando, 2007). With a view to introduce new varieties, the Farmers' Participatory Varietal Selection (FPVS) programme was implemented during in selected districts of Hyderabad-Karnataka region.

\section{Materials and Methods}

The experiment was conducted during kharif2015 and rabi/summer 2015-16 in selected districts of Hyderabad-Karnataka region. Prior to this needs of the farmers were assessed to set goals and identify farmers preference and perception on ideotype of groundnut cultivars. Based on assessments nine high yielding groundnut genotypes (Table 1) were selected from various research institutes across India along with farmer's variety as check. The experiment was implemented through Mother-baby approach (Snapp, 1999) in the villages of selected districts in Hyderabad-Karnataka region where groundnut cultivation is predominant (Table 2). From each village 11 beneficiary farmers were selected to conduct the experiment, among 11 farmers one farmer will conduct mother trail which means it includes all the ten genotypes and rest of the ten farmers will conduct baby trails in paired comparison i.e., $\mathrm{V} 1+\mathrm{V} 2, \mathrm{~V} 2+\mathrm{V} 3 \ldots \mathrm{V} 10+\mathrm{V} 1$ (Fig. 1, Table 2). Hence there will be three replications for each variety in a village. Each mother trail comprised of $1000 \mathrm{~m} 2$ area where baby trails were of $200 \mathrm{~m} 2$ area. In a trail, each variety was sown 10 rows with spacing of $30 \times 10 \mathrm{~cm}$ by following necessary agronomic practices. The experimental kit (seeds, plant protection chemicals and micronutrients) was distributed to all the beneficiary farmers to conduct the experiment in a precise manner. Regular field visits were made at a fortnight interval to each location.

A uniform area $(100 \mathrm{~cm} 2)$ of each variety were used to record the observation on dry pod yield $(\mathrm{kg})$ then converted to dry pod yield (kg/ha). Farmers preference towards varieties were recorded during field days organized at mother trail site using questionnaires and farmers were asked to select the top three varieties with preference of I, II and III accordingly, then percent preference towards each genotype was worked out. Preference of other stakeholders like traders, oil millers, extension workers, seed production agencies and agriculture related officials were recorded by organizing the on-campus training programme using simple ranking method. Stakeholders were asked to rate the varieties from " 1 " being least preferred, "2" is preferred and " 3 " being most preferred for each trait. Mean ranking for the traits i.e.. seed size, seed shape, testa colour, pod size, 
pod shape, pod filling, shelling (\%), oil content and market price were worked out using 'matrix ranking' method (Bucheyeki et al., 2008).

\section{Results and Discussion}

The dry pod yields ( $\mathrm{kg} / \mathrm{ha})$ of all test genotypes across the location and seasons are presented in table 3 . It was revealed from the results that, in kharif, GPBD-5 (1573 kg/ha), Kadiri-9 (1492 kg/ha) and ICGV-00351 (1481 $\mathrm{kg} / \mathrm{ha}$ ) were statistically significant over farmers variety TMV-2 $(1276 \mathrm{~kg} / \mathrm{ha})$. Where in rabi/summer, ICGV-00351 (1693 kg/ha), GPBD-5 (1649 kg/ha) and Kadiri-9 (1589 $\mathrm{kg} / \mathrm{ha}$ ) were significantly superior than TMV2 (1406 kg/ha). Similarly, Adu-Dapaah et al., (2004 \& 2007), Natre et al., (2008) and Vindhiyaraman et al., (2010) reported the higher yields of ICRISAT groundnut genotypes over local checks. Where, success of improved barley lines in Syria (Veroony et al., 2003), aromatic rice (pokhreli jethobodo) in Nepal (gyawali et al., 2010) and GDRM187 maize variety in Rajasthan (Gramina vikas trust, 2002) through participatory research approach also reported. Interestingly, it was observed that dry pod yields $(\mathrm{kg} / \mathrm{ha})$ of all the genotypes were high in rabi/summer compare to kharif season. It may be attributed as rabi/summer crop will be taken under assured irrigation conditions where in kharif season, mostly under rainfed conditions.

Magnitude of $\mathrm{G} \times \mathrm{E}$ interaction in a variety decides its fitness in particular agro-climatic zones. GxE interaction is a good indication of biotic and abiotic factors affecting the crop production in their respective areas (Benziger et al., 2006). In the present study, experimental sites were located in two major agro-climatic zones of Karnataka i.e., North eastern dry zone and northern dry zone, hence, as expected each variety shown difference in yield performance in different location. Similarly Bucheyeki et al., (2008) reported $\mathrm{G} \times \mathrm{E}$ interaction in test genotypes. The dry pod yields $(\mathrm{kg} / \mathrm{ha})$ of all varieties in each location are presented in table 3 . In kharif, test genotypes found to be significantly better than TMV-2 (1275 kg/ha) in each location i.e., in Golapalli (TG37A:1496 kg/ha, Kadiri-9: $1423 \mathrm{~kg} / \mathrm{ha}$ and Kadiri Haritandra:1384 $\mathrm{kg} / \mathrm{ha}$ ), Shrinivasapura (ICGV-003521: $1659 \mathrm{~kg} / \mathrm{ha}$, GPBD-5: $1611 \mathrm{~kg} / \mathrm{ha}$ and Kadiri-9: 1409 $\mathrm{kg} / \mathrm{ha}$ ), Chikkakolache (GPBD-5: $1891 \mathrm{~kg} / \mathrm{ha}$, G2-52: 1629 kg/ha, Kadiri -9: 1546 kg/ha), Sasvigera (TPG-41:1591 kg/ha, Kadiri -9: $1524 \mathrm{~kg} / \mathrm{ha}$ and GPBD-5: $1452 \mathrm{~kg} / \mathrm{ha}$ ) and Thigari (Kadiri-9: 1565 kg/ha). During rabi/summer, at Golapalli (Kadiri-9: 1713 $\mathrm{kg} / \mathrm{ha}$, Dharani:1681 kg/ha and ICGV-00351: $1638 \mathrm{~kg} / \mathrm{ha}$ ), Gogi tanda (ICGV-00351: 1804 kg/ha), Chikkakolache (GPBD-5: 1819 $\mathrm{kg} / \mathrm{ha}$ ), Sasvigera (GPBD-5: $1648 \mathrm{~kg} / \mathrm{ha}$, TG37A:1645 kg/ha, Dharani: $1626 \mathrm{~kg} / \mathrm{ha}$ ) and in Thigari (ICGV-00351: $1830 \mathrm{~kg} / \mathrm{ha}$, Kadiri9:1674 kg/ha, Kadiri haritanra: $1671 \mathrm{~kg} / \mathrm{ha}$ ) genotypes were better yielder than farmer variety. It can be inferred from the studies that Kadiri-9, ICGV-00351 and GPBD-5 found to be more or less stable yielder across the location and over seasons. Similarly, Bucheyeki et al., (2008) reported the stable yields of Pendo and Johari groundnut varieties in Nigeria.

\section{Varietal preference analysis}

In varietal preference analysis, a simple ranking by the farmers based on their selection criterion were used. At harvest/field days, farmers were asked to rank the top three varieties based on their selection criteria. It was observed that most of the farmers were preferred varieties based pod features and haulm quality. The preference towards genotypes is presented in table 4 . In Kharif, a total of 1392 ranking were recorded from farmers, out of which Kadiri-9 was most 
preferred variety with $316(22.70 \%)$ rankings either as I, II. or III choice, which is followed by GPBD-5 (216 ranks, $15.52 \%$ ) and Dharani (208 ranks, $14.94 \%$ ). It may be attributed to, all these genotypes shown comparatively good yield coupled with good tolerance to pests and diseases. Similarly, in rabi/summer, a total of 810 rankings were recorded, among top three varieties preferred by farmers, Kadiri-9 stood first with 18.15 per cent preference (147 ranks), followed by ICGV00351 (137 ranks, $16.91 \%$ ) and GPBD-5 (104 ranks, $12.84 \%)$.

Table.1 List of varieties tested and their important features

\begin{tabular}{|c|c|c|c|}
\hline $\begin{array}{l}\text { Sl. } \\
\text { No. }\end{array}$ & Variety Name & Developed Station & Specific features \\
\hline 1 & Kadiri-9 & $\begin{array}{l}\text { UAS, Raichur/ } \\
\text { ARS, Kadiri }\end{array}$ & $\begin{array}{l}\text { High yield (22-25 q/ha), High oil content }(48-50 \%) \text {, } \\
\text { Drought tolerant, Moderately resistant to foliar } \\
\text { diseases }\end{array}$ \\
\hline 2 & ICGV-00351 & $\begin{array}{l}\text { UAS,Raichur/ } \\
\text { ICRISAT/TNAU }\end{array}$ & $\begin{array}{l}\text { High yield (22-27 q/ha), High oil content }(48-51 \%), \\
\text { Drought tolerant, Moderately resistant to foliar } \\
\text { diseases }\end{array}$ \\
\hline 3 & Dharani & RARS, Tirupati & $\begin{array}{l}\text { High yield, Drought tolerant, tolerant to leaf spots and } \\
\text { suitable to rainfed areas. }\end{array}$ \\
\hline 4 & Kadiri Haritandra & ARS, Kadiri & $\begin{array}{l}\text { High yield, Drought tolerant, Moderately resistant to } \\
\text { foliar diseases }\end{array}$ \\
\hline 5 & TG-37A & BARC, Mumbai & $\begin{array}{l}\text { High yield }(22-25 \mathrm{q} / \mathrm{ha}), \text { Bold seeded, Smooth pods, } \\
\text { High harvest index }\end{array}$ \\
\hline 6 & TPG-41 & BARC, Mumbai & Table purpose, Large seeded, O/L ratio 3.2 \\
\hline 7 & TG-51 & BARC, Mumbai & High yield $(25-27 \mathrm{q} / \mathrm{ha})$, oil content $(49 \%)$ \\
\hline 8 & $\mathrm{G}_{2}-52$ & UAS, Dharwad & $\begin{array}{l}\text { Resistant to Late leaf spot and Rust diseases, High } \\
\text { yield ( } 25-30 \mathrm{q} / \mathrm{ha}) \text {, Good kernel feature as TMV-2 }\end{array}$ \\
\hline 9 & GPBD-5 & UAS, Dharwad & $\begin{array}{l}\text { Resistant to leaf spots, High yielder (25-30 q/ha), } \\
\text { Bold seeded. }\end{array}$ \\
\hline 10 & $\begin{array}{l}\text { TMV } \\
\text { (Farmers variety) }\end{array}$ & $\begin{array}{l}\text { UAS, } \\
\text { Raichur/TNAU }\end{array}$ & $\begin{array}{l}\text { Widely adoptable, Susceptible to pest and diseases } \\
\text { and low yielder. }\end{array}$ \\
\hline
\end{tabular}

Table.2 List of FPVS trials conducted during Kharif-2015 and rabi/summer-2015-16

\begin{tabular}{|l|l|c|c|c|c|}
\hline Season & \multicolumn{2}{|c|}{ Kharif-2015 } & \multicolumn{2}{c|}{ rabi/summer- 2015-16 } \\
\hline $\begin{array}{l}\text { Name of } \\
\text { Districts }\end{array}$ & Name of Locations & Mother trail & Baby trails & Mother trail & Baby trails \\
\hline \multirow{2}{*}{ Raichur } & Devadurga: Sasvigera & 1 & 10 & 1 & 10 \\
\cline { 2 - 6 } & Lingasuguru: Golapalli & 1 & 10 & 1 & 10 \\
\hline \multirow{2}{*}{ Yadgir } & Surapura: Shrinivaspura & 1 & 10 & - & - \\
\cline { 2 - 6 } & Surapura: Gogi tanda & - & - & 1 & 10 \\
\hline \multirow{2}{*}{ Bellary } & Bellary: Hagari & 1 & 10 & 1 & 10 \\
\cline { 2 - 6 } & $\begin{array}{l}\text { Huvinahadagali: } \\
\text { Chikkakolachi }\end{array}$ & 1 & 10 & 1 & 10 \\
\hline Koppal & Koppal: Thighari & 1 & 10 & 1 & 10 \\
\hline \multicolumn{2}{l}{ Total } & $\mathbf{6}$ & $\mathbf{6 0}$ & $\mathbf{6}$ & $\mathbf{6 0}$ \\
\hline
\end{tabular}


Table.3 Mean performance of test genotypes for dry pod yield $(\mathrm{kg} / \mathrm{ha})$ under FPVS trials at different location during Kharif and rabi/summer 2015-16

\begin{tabular}{|c|c|c|c|c|c|c|c|c|}
\hline Sl.No. & $\begin{array}{c}\text { Name of } \\
\text { Genotypes }\end{array}$ & Season & Golapalli & Srinivasapura & Chikkakolachi & Sasvigera & Thigari & Pooled \\
\hline \multirow{2}{*}{1} & \multirow{2}{*}{ Kadiri-9 } & Kh-2015 & 1423 & 1403 & 1546 & 1524 & 1565 & 1492 \\
\hline & & $R / S-2015-16$ & 1713 & 1536 & 1647 & 1507 & 1673 & 1588 \\
\hline \multirow{2}{*}{2} & \multirow{2}{*}{ ICGV-00351 } & Kh-2015 & 1275 & 1659 & 1545 & 1432 & 1492 & 1481 \\
\hline & & $R / S-2015-16$ & 1637 & 1804 & 1575 & 1620 & 1830 & 1693 \\
\hline \multirow{2}{*}{3} & \multirow{2}{*}{ Dharani } & Kh-2015 & 1299 & 1167 & 1388 & 1384 & 1414 & 1330 \\
\hline & & $R / S-2015-16$ & 1681 & 1304 & 1405 & 1626 & 1506 & 1478 \\
\hline \multirow{2}{*}{4} & \multirow{2}{*}{$\begin{array}{c}\text { Kadiri } \\
\text { Haritandra }\end{array}$} & $K h-2015$ & 1384 & 1242 & 1295 & 1340 & 1347 & 1322 \\
\hline & & $R / S-2015-16$ & 1405 & 1434 & 1411 & 1347 & 1671 & 1454 \\
\hline \multirow{2}{*}{5} & \multirow{2}{*}{ TG-37A } & Kh-2015 & 1496 & 1148 & 1379 & 1285 & 1417 & 1345 \\
\hline & & $R / S-2015-16$ & 1575 & 1380 & 1525 & 1644 & 1595 & 1550 \\
\hline \multirow{2}{*}{6} & \multirow{2}{*}{ TPG-41 } & Kh-2015 & 1362 & 1377 & 1264 & 1591 & 1340 & 1386 \\
\hline & & $R / S-2015-16$ & 1550 & 1565 & 1437 & 1568 & 1401 & 1504 \\
\hline \multirow{2}{*}{7} & \multirow{2}{*}{ TG-51 } & Kh-2015 & 1360 & 1108 & 1220 & 1210 & 1265 & 1233 \\
\hline & & $R / S-2015-16$ & 1405 & 1700 & 1384 & 1347 & 1315 & 1430 \\
\hline \multirow{2}{*}{8} & \multirow{2}{*}{$\mathrm{G} 2-52$} & Kh-2015 & 1195 & 1232 & 1629 & 1379 & 1416 & 1370 \\
\hline & & $R / S-2015-16$ & 1420 & 1455 & 1633 & 1420 & 1455 & 1476 \\
\hline \multirow{2}{*}{9} & \multirow{2}{*}{ GPBD-5 } & Kh-2015 & 1369 & 1611 & 1891 & 1452 & 1539 & 1573 \\
\hline & & $R / S-2015-16$ & 1546 & 1595 & 1818 & 1647 & 1637 & 1649 \\
\hline \multirow{8}{*}{10} & \multirow[t]{2}{*}{ TMV-2 } & Kh-2015 & 1243 & 1213 & 1352 & 1249 & 1278 & 1267 \\
\hline & & $R / S-2015-16$ & 1318 & 1492 & 1504 & 1321 & 139 & 1406 \\
\hline & \multirow{2}{*}{ Mean } & Kh-2015 & 1341 & 1316 & 1451 & 1385 & 1407 & 1380 \\
\hline & & $R / S-2015-16$ & 1525 & 1526 & 1534 & 1505 & 1548 & 1523 \\
\hline & \multirow{2}{*}{$\mathrm{CD}_{(5 \%)}$} & $K h-2015$ & 324.82 & 357.16 & 177.04 & 396.04 & 275.21 & 150.64 \\
\hline & & $R / S-2015-16$ & 221 & 254 & 249 & 252 & 273 & 179 \\
\hline & \multirow{2}{*}{ CV (\%) } & Kh-2015 & 14.12 & 15.82 & 15.48 & 16.67 & 18.40 & 10.51 \\
\hline & & $R / S-2015-16$ & 13 & 14.7 & 14.8 & 14.8 & 15.3 & 14.2 \\
\hline
\end{tabular}

Fig.1 Schematic representation of adopted mother-baby trail approach to conduct

FPVS experiment

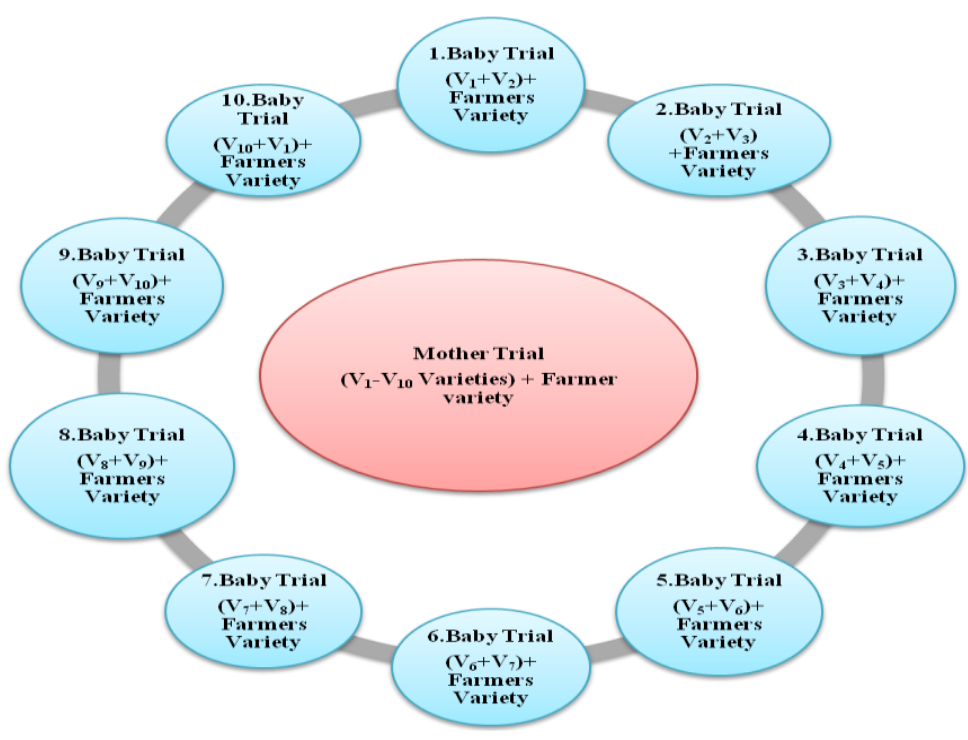


Table.4 Overall Farmer preference of test genotypes during Kharif and rabi/summer 2015-16

\begin{tabular}{|c|c|c|c|c|c|c|c|}
\hline \multirow{2}{*}{ Sl. No. } & \multirow{2}{*}{ Name of Genotypes } & \multirow{2}{*}{ Season } & \multicolumn{3}{|c|}{ Ranking } & \multirow{2}{*}{$\begin{array}{c}\text { Total } \\
\text { Rankings }\end{array}$} & \multirow{2}{*}{$\begin{array}{c}\text { Percent } \\
\text { preference }\end{array}$} \\
\hline & & & I & II & III & & \\
\hline \multirow{2}{*}{1} & \multirow{2}{*}{ Kadiri-9 } & $K h-2015$ & 188 & 66 & 62 & 316 & 22.70 \\
\hline & & $R / S-2015-16$ & 73 & 45 & 29 & 147 & 18.15 \\
\hline \multirow{2}{*}{2} & \multirow{2}{*}{ ICGV-00351 } & $K h-2015$ & 52 & 82 & 28 & 162 & 11.64 \\
\hline & & $R / S-2015-16$ & 76 & 43 & 18 & 137 & 16.91 \\
\hline \multirow{2}{*}{3} & \multirow{2}{*}{ Dharani } & $K h-2015$ & 54 & 60 & 94 & 208 & 14.94 \\
\hline & & $R / S-2015-16$ & 32 & 24 & 26 & 82 & 10.12 \\
\hline \multirow{2}{*}{4} & \multirow{2}{*}{ Kadiri Haritandra } & $K h-2015$ & 10 & 28 & 26 & 64 & 4.60 \\
\hline & & $R / S-2015-16$ & 15 & 27 & 11 & 53 & 6.54 \\
\hline \multirow{2}{*}{5} & \multirow{2}{*}{ TG-37A } & $K h-2015$ & 18 & 40 & 24 & 82 & 5.89 \\
\hline & & $R / S-2015-16$ & 34 & 42 & 14 & 90 & 11.11 \\
\hline \multirow{2}{*}{6} & \multirow{2}{*}{ TPG-41 } & $K h-2015$ & 10 & 38 & 22 & 70 & 5.03 \\
\hline & & $R / S-2015-16$ & 8 & 15 & 11 & 34 & 4.20 \\
\hline \multirow{2}{*}{7} & \multirow{2}{*}{ TG-51 } & $K h-2015$ & 4 & 22 & 14 & 40 & 2.87 \\
\hline & & $R / S-2015-16$ & 2 & 19 & 23 & 44 & 5.43 \\
\hline \multirow{2}{*}{8} & \multirow{2}{*}{$\mathrm{G}_{2}-52$} & $K h-2015$ & 36 & 40 & 40 & 116 & 8.33 \\
\hline & & $R / S-2015-16$ & 20 & 21 & 17 & 58 & 7.16 \\
\hline \multirow{2}{*}{9} & \multirow{2}{*}{ GPBD-5 } & $K h-2015$ & 72 & 56 & 86 & 216 & 15.52 \\
\hline & & $R / S-2015-16$ & 35 & 23 & 46 & 104 & 12.84 \\
\hline \multirow{4}{*}{10} & \multirow{2}{*}{ TMV-2 } & $K h-2015$ & 28 & 44 & 46 & 118 & 8.48 \\
\hline & & $R / S-2015-16$ & 15 & 13 & 33 & 61 & 7.53 \\
\hline & \multirow{2}{*}{ Total } & $K h-2015$ & & & & 1392 & \\
\hline & & $R / S-2015-16$ & & & & 810 & \\
\hline
\end{tabular}

Table.5 Mean Varietal preference ranking of stakeholders

\begin{tabular}{|c|c|c|c|c|c|c|c|c|c|c|}
\hline \multirow[b]{2}{*}{ Trait of variety } & \multicolumn{10}{|c|}{ Variety } \\
\hline & K-9 & $\begin{array}{c}\text { ICGV- } \\
00351\end{array}$ & Dharani & $\begin{array}{c}\text { Kadiri } \\
\text { Haritandra }\end{array}$ & $\begin{array}{l}\text { TG- } \\
37\end{array}$ & $\begin{array}{c}\text { TPG- } \\
41\end{array}$ & $\begin{array}{c}\text { TG- } \\
51\end{array}$ & $\begin{array}{l}\mathrm{G}_{2^{-}} \\
52\end{array}$ & $\begin{array}{c}\text { GPBD- } \\
5\end{array}$ & TMV-2 \\
\hline Seed size $(\mathrm{mm})$ & 2 & 2 & 1 & 2 & 2 & 2 & 1 & 2 & 2 & 2 \\
\hline Seed shape & 2 & 2 & 1 & 2 & 2 & 2 & 1 & 2 & 2 & 2 \\
\hline Testa colour & 2 & 2 & 1 & 2 & 2 & 2 & 1 & 2 & 2 & 2 \\
\hline Pod size $(\mathrm{cm})$ & 2 & 2 & 2 & 2 & 2 & 2 & 2 & 2 & 2 & 2 \\
\hline Pod shape & 2 & 2 & 1 & 2 & 2 & 2 & 2 & 2 & 2 & 2 \\
\hline Pod filling & 2 & 2 & 2 & 2 & 2 & 2 & 2 & 2 & 2 & 2 \\
\hline Shelling (\%) & 2 & 2 & 2 & 2 & 2 & 2 & 2 & 2 & 2 & 2 \\
\hline Oil content $(\%)$ & 3 & 2 & 2 & 2 & 1 & 2 & 1 & 2 & 2 & 2 \\
\hline Market price (Rs) & 2 & 2 & 2 & 2 & 2 & 2 & 1 & 2 & 2 & 2 \\
\hline Total rankings & 19 & 18 & 14 & 18 & 17 & 18 & 13 & 18 & 18 & 18 \\
\hline Preference rank & I & II & IV & II & III & II & $\mathbf{V}$ & II & II & II \\
\hline
\end{tabular}

*Note: 1- Least preferred, 2- Preferred, 3-Most preferred *Sample size: 50

Similarly Vindhiyaraman et al., (2010) reported ICGV-87846 as most preferred variety by farmers in Tamilnadu, Bucheyeki et al., (2008) found that Johari and Pendo varieties were most preferred by farmers in Nigeria and Dwivedi (2006) reported strong preference of GR-17 rice variety than local genotypes. Ndjeunga et al., (2010) and
Monyo (2007) reported that, varieties preferred by farmers are site specific and that variety recommendations should be targeted to specific domains where varieties are preferred by farmers.

The varietal preference of stakeholders were recorded by organizing the on-campus 
training programme Stakeholders were asked to rate the varieties from "1" being least preferred to " 3 " being most preferred. Mean ranking for the important traits (seed size, seed shape, test a colour, pod size, pod shape, pod filling, shelling (\%), oil content and market price) are preference ranks are presented in table 5. Results revealed that, mean ranking for most of the traits in each variety recorded preference rank (2). It indicates that, all the test genotypes were having desirable features because most of them were newly developed, high yielding varieties from different research institutes. Based on the total rankings (sum of mean ranking of all the traits) shown that Kadiri-9 scored a total of 19 ranking, which is highest among others, hence it was attributed with overall preference rank of I. Whereas, other genotypes scored total rankings of 18 (ICGV00351, Kadiri-haritendra, TPG-41, TMV-2, G2-52 and GPBD-5) which were attributed with the overall preference rank of II. However, TG-37A (17), Dharani (14) and TG-51 (13) were least preferred and those were attributed with overall preference rank of III, IV and V respectively. Similarly, ICGV 87846 recorded the most preferred category for all the traits in Tamilnadu (Vindhiyaraman et al., 2010) and ICGV-91114 in Anathpur district of Andhra-Pradesh (Nigam et al., 2005). Tatlonghari et al., (2009) reported that farmers preferred rice varieties with high fertilizer response and submergence tolerance.

By considering the FPVS experimental data as well as preference data from farmer and other stakeholders, it can be revealed that test genotypes Kadiri-9, GPBD-5, ICGV-00351 and Dharani were most preferred cultivars. Based on the results it can be concluded that, farmers participatory varietal selection (FPVS) provide golden opportunity to farmers as it enables them to opt of their choice of varieties under their own conditions, environment and availability of resource. This is consistent with earlier findings (Vindhiyavarman et al., 2010; Adu-Dapaah et al., 2007; Ntare et al., 2007; ICRISAT, 20022004; Govindraj et al., 2009; Ndjeunga et al., 2010). It was also observed that farmers were not only looking for yield and also for other desirable traits like disease and pest resistance, drought tolerance, fodder quality and more importantly marketability of varieties, as it illustrated by farmers preference that Kadiri-9 being moderately resistant to diseases, drought tolerant coupled with high yield and GPBD-5 being resistant of foliar diseases ensures high fodder quality with higher yields. Hence farmer's participatory varietal selection (FPVS) opens the avenues for improved varieties to reach farming community, in turn increase in production and productivity of groundnut.

\section{Acknowledgements}

The RKVY cell, Govt. of Karnataka provided the funded for conducting the experiment.

\section{References}

Adu-Dapaah, H.K., Asibuo, J.Y., Danquah, O.A., Asumadu, H., Haleegoah, J. and Asafo-Adeji, B. 2004. Farmer's participation in groundnut rosette resistant varietal selection in Ghana. In: Fisher et al., (eds). New direction for diverse planet: Proceedings for the 4th international crop science congress, Brisbane, Australia, 26th September1st October, pp. 1-10.

Adu-Dapaah, H.K., Asumadu, H., Lamptey, J.N.L., Haleegoah, J. and Asafo-Aajei, B. 2007. Farmer Participation in Groundnut selection, African Crop Science Proceedings, 8: 1435-1439.

Ceccarelli, S., Grando, S. 2007. Decentralized participatory plant breeding: an example of Demand driven research. Euphytica, 155: 349 -360. 
Dwivedi, Y.K. 2006. Participatory varietal selection and promotion programme. Leisa India, September, pp. 18-19.

Govindaraj, G., Satish Kumar, G.D. and Basu, M.S. 2009. Benefits of Improved Groundnut Technologies to Resourcepoor Farmers: A Participatory Approach. Agril. Economics Res. Rev., 22: 355-360.

Gramin Vikas Trust. 2002. WIRFP participatory plant breeding: concepts and examples, No. 3, Sunrise printers, Udaipur, pp. 1-4.

Gyawali, S., Sthapit, B.R., Bhandari, B., Bajracharya, J., Shrestha, P.K., Upadhyay, M.P., and Jarvis, D. I. 2010. Participatory crop improvement and formal release of Jethobudho rice land race in Nepal. Euphytica, 176: 59-78.

ICRISAT. 2002-2004. Programme for farmer participatory improvement of grain legumes in rainfed Asia. Progress Reports: IFAD Technical Assistance Grant No. 532. Patancheru 502 324, Andhra Pradesh, India: International Crops Research Institute for the SemiArid Tropics. pp. 1-8.

Joshi, A. and Witcombe, J.R. 1995. Farmer Participatory Crop Improvement. II Participatory Varietal Selection, a case studies in India. Exp. Agric., 32: 461477.

Ministry of Agriculture, Govt. of India. 2016. Indiastat (http:// www.indiastat.com)

Monyo, E.S. 2007. Development of short and medium duration and groundnut varieties with improved yield performance, acceptable market traits and resistance to foliar diseases. ICRISAT Progress report (September1st 2006 to August 31st 2007), pp. 1-30.

Ndjeunga, J., Ntare, B.R., Abdoulaye, A., Ibro, A., Zarafi, M.A., Cisse, Y., Moutari, A., Kodio, O., Echekwu, C. A., Mohammed, S.G. and Micko, I. 2010. Farmer preferences for groundnut traits and varieties in West Africa: Cases of Mali, Niger and Nigeria. Working Paper Series no. 27. Patancheru 502 324, Andhra Pradesh, India: International Crops Research Institute for the Semi-Arid Tropics, pp.32.

Nigam, S.N., Aruna, R., Yadagiri, R., Reddy, T.Y., Subramanyam, K., Reddy, B.R. R. and Kareem, K.R. 2005, Farmer Participatory Varietal Selection in Groundnut - A Success Story in Anantapur, Andhra Pradesh, India. Int. Crops Res. Institute Semi-Arid Tropics, Pp.1-3.

Ntare, B.R., Ndjeunga, J., Waliyar, F., Kodio, O., Echekwu, C.A., Kapran, I., Da Sylva, A., Diallo, A.T., Amadou, Bissala, H.Y. and Sako, K. 2007. Farmer Participatory Evaluation and Dissemination of Improved Groundnut Varieties in West Africa. Int. Crops Res. Institute Semi-Arid Tropics, pp.36.

Pande, S., Bandyopadhyay, R., Blümmel, M., Narayana Rao, J., Thomas, D. and Navi, S.S. 2003. Disease management factors influencing yield and quality of sorghum and Groundnut crop residues. Field Crops Res., 84(1-2): 89-103.

Snapp, S. 1999. Mother and baby trials: a novel trial design being tried out in Malawi. Target -Newsletter of the South African Soil Fertility Network, 17: 8-10.

Tatlonghari, G., Manivong, V., Siliphuothone, I.G., Paris, T. and Manzanilla, D. 2009. Incorporating a gender perspective in validating varieties for submergence prone rice-based farming systems in selected villages in central and southern laos. Social science division, International Rice Research Institute, Philippines. pp. 111.

Upadhyaya, H.D., Reddy, L.J., Gowda C.L.L., Singh, S. 2006. Identification of diverse groundnut germplasm: Sources 
of early maturity in a core collection. Field Crops Res., 97(2-3): 261-271.

Vernooy, R. and Stanely, B. 2003. 'Breeding better barley-together. A new way to work with farmers in dry areas'. International development research centre, Ottowa.

Vindhiyavarman, P., Manivannan, N., Nigam, S.N. and Muralidharan, V. 2010.
Farmers' participatory varietal selection in Groundnut: A case study from Tamilnadu, India, Electron. J. Plant Breed, 1(4): 878-881.

Walker, T.S. 2007. Participatory Varietal Selection, Participatory Plant Breeding, and Varietal Change. Background paper for the World Bank development report, 2008.

\section{How to cite this article:}

Hasan Khan, Vinay S. Patted, Muralidhara B., Shankergoud I. and Salimath P. M.. 2017. Study on Impact of Farmer's Participatory Varietal Selection in Groundnut (Arachis hypogeae L.) Improvement. Int.J.Curr.Microbiol.App.Sci. 6(6): 1304-1312. doi: https://doi.org/10.20546/ijcmas.2017.606.153 